\title{
PENERAPAN MODEL COSO UNTUK PENINGKATAN FUNGSI PENGENDALIAN INTERNAL: STUDI PADA AGENCY ADMINISTRAÇÃO DE AEROPORTO E NAVEGAÇÃO AÉREA DE TIMOR-LESTE
}

\author{
Verissimo Nai Sia \\ Sekolah Pascasarjana Fakultas Ekonomi dan Bisnis Universitas Airlangga \\ verissimonai@yandex.com
}

\section{ARTICLE HISTORY}

Received:

9 July 2019

Revised

15 August 2019

Accepted:

1 September 2019

Online available:

10 November 2019

Keywords :

internal control, coso framework, efficient and effective.

\begin{abstract}
Implementation of internal controls is a basic principle for internal/external auditing. Internal control becomes a basic framework to operate effectiveness and efficiency of organization activities. Implementation of the COSO internal control for ANATL agency is to improve the actual system of internal control at Dili airport, and also as requirements from ICAO standards. Requirements of air transport services, such as: (1) increased efficiency, (2) reduce costs, and (3) safety and security. This study tried to find out the implementation and problems of internal control in the agency ANATL, by comparison with the COSO framework.

Theories of COSO internal control model stated three groups of the objectives, namely: 1) Effectiveness and efficiency of operations, 2) Reliability of financial reporting, and 3) Compliance with applicable laws and regulations. Achieving the three objectives there are five basic components of internal control system such as: Control Environment, Risk Assessment, Control Activities, Information and Communication, and Monitoring.

The study was conducted with qualitative methods to verify the theory of proposition 1: If implementation of internal control as a whole, then the performance of agency ANATL will be very good, and proposition 2: Quality of internal control is getting better, the arising of risk could be reduced and fraud preventable.

The results had shown that implementation of internal control as framework COSO order in the agency ANATL was very weak. Weakness almost among categories and components of internal control therefore not applied completely. The category of weakness was financing reporting and compliance with laws and regulations. While the components were very weak such as control environment, control activities and monitoring. The proposition 1 is answered: the implementation internal control in agency ANATL is not completed cause poor performance. Poor quality of internal controls or inadequate, then the proposition 2 answered: the poor quality of the internal control will be risk and fraud.
\end{abstract}


Jurnal Ekonomi dan Bisnis Airlangga, Vol. 29, No.2, June - November 2019

\section{LATAR BELAKANG}

Penerapan pengendalian internal yang efektif merupakan prinsip dasar internal audit. Hal ini berarti pengendalian internal menjadi sebuah kerangka dasar dalam setiap pelaksanaan kegiatan operasional sehingga menjadi efektif, dan untuk memastikan efektivitas maka aktivitas utama internal/eksternal audit adalah sebagai fungsi penilai independen untuk meninjau kegiatan pada semua tingkatan manajemen. Dengan demikian fungsi audit yaitu mengukur, mengevaluasi dan melaporkan pada efektivitas dari pada penerapan sistem pengendalian internal.

Fungsi audit internal merupakan bagian integral dari sistem pengendalian internal, dan audit internal tidak hanya harus melaporkan pada efektifitas pengendalian internal tetapi juga harus membuat rekomendasi untuk memperbaikinya. Hasil survei Internal Audit State of the Profession (2013) yang digelar oleh PWC Amerika Serikat mengindikasikan fungsi dan kinerja audit internal unggul dalam empat lini penting, yakni: (1) mendemonstrasikan kapabilitas dasar yang lebih kuat; (2) berkoordinasi dengan atasan organisasi; (3) menjalankan aktivitas seperti risiko dan kepatuhan, menggabungkan risiko yang muncul dan pemberian saran proaktif, serta (4) aktif melibatkan diri dengan manajemen dalam menyusun inisiatif organisasi.

Pentingnya pengendalian internal ini menyebabkan setiap organisasi, baik pemerintah, swasta, publik ataupun lembaga professional, dewasa ini memberikan perhatian khusus terhadap hal ini. Timor-Leste yang merupakan negara terbaru di dunia, jika institusi-institusi yang ada di Dalam Negeri seperti agency Administração de Aeroportos e Navegação Aérea de Timor-Leste (ANATL) tidak segera menyesuaikan diri seperti antara lain; menerapkan pengendalian internal sesuai perubahan yang ada, akan semakin tertinggal jauh dengan Negara di kawasan Asia lainnya.

Penerapan pengendalian internal COSO bagi agency ANATL juga sebagai implementasi atas tuntutan (requirement) dari standar Organisasi Penerbangan Sipil Internasional--International Civil Aviation Organization-(ICAO). Requirement atas penyelenggaraan transportasi udara, mencakup tiga hal; (1) peningkatan efisiensi, (2) menekan biaya-biaya, dan (3) tetap mempertahankan keamanan (safety). Dengan demikian manajemen ANATL diharapkan memiliki sistem pengendalian internal yang dirancang sebagai kebijakan dan pedoman untuk dilaksanakan oleh staf untuk memenuhi tuntatan ini.

Penerapan pengendalian internal pada saat dipegang ANA Consórcio, SA (masa peralihan yang disiapkan PBB) berjalan efisien dan efektif. Akhir-akhir ini ada fenomenafenomena yang menjadi sorotan media, seperti: Adanya penyimpangan sebagaimana dilansir SAPO TL Suara Timor Lorosa'e tanggal 28 Oktober 2011 bahwa Staf Operasional International Airport Presidente Nicolau Lobato mengancam melakukan mogok karena kurangnya tunjangan. Karyawan yang diwakili Jacinto Ximenes selaku juru bicara 
memohon Menteri Infrastruktur agar cepat merespon kasus ini. Karyawan lain (Atanazio Fernandes) meminta pihak berwenang yaitu Komisi Anti Korupsi (CAC=Comissão AntiCorrupção), Ombudsman Keadilan dan Hak Asasi Manusia (Provedoria dos Direitos Humanos e Justiça) dan Komisi Pelayanan Publik (Comissão da Função Pública), untuk melakukan investigasi atas penyimpangan dalam proses perekrutan beberapa pejabat di Penerbangan Sipil.

Dalam kaitan dengan kinerja pegawai ANATL, Perdana Menteri Timor-Leste (2012) memberi sindiran bahwa pegawai agency ANATL sama seperti pesawat Merpati saja, pesawat take off, pegawai menghilang juga. Perdana Menteri menyindir oleh karena tidak puas terhadap pengawai-pegawai dalam menjalankan tugasnya.

Informasi akhir yang diperoleh dari media online Tempo Semanal tanggal 25 Desember 2013 bahwa pejabat/pegawai duty ship tidak memberikan pelayanan terhadap pesawat Airnorth yang hendak terbang kembali ke Darwin. Tindakan seperti ini tidak sesuai Standard Operations Procedure (SOP) atau aturan-aturan penerbangan yang ada.

Fenomena-fenomena yang ada dan kinerja personil yang tidak memadai, berindikasi lemahnya kepatuhan (compliance) terhadap aturan-aturan yang telah ditetapkan. Adanya perbedaan interpretasi dalam implementasi atau pelaksanaan operasional sehingga kegiatan operasi tidak efisien dan efektif merupakan sinyal lemahnya pengendalian internal.

Atas dasar hal-hal yang diuraikan diatas, mendorong penulis untuk melihat kondisi pengendalian internal aktual untuk penyelesaian permasalahan (problem sovling) yang ada dengan menerapkan pengendalian internal model COSO. Walapun pada saat ini kuantitas penerbangan yang terjadi di bandara Dili masih minim, ada baiknya perlu menerapkan pengendalian internal berbasiskan model COSO sehingga berbagai bentuk kesalahan dan kecurangan (fraudulent) dapat dihindari. Organisasi-organisasi besar maupun kecil di luar negeri (di luar Timor-Leste) juga mengadopsi dan menerapkan framework COSO.

Framework COSO menyediakan penjelasan dalam konsep multi dimensional atas penegendalian internal. Karena itu model COSO didisain untuk memberikan keyakinan memadai tentang pencapaian tiga kelompok tujuan yaitu: (1) Efisiensi dan Efektivitas Operasi, (2) Keandalan Pelaporan Keuangan, dan (3) Kepatuhan terhadap Hukum dan regulasi-regulasi yang berlaku. Untuk mencapai tujuan itu terdapat lima komponen pokok sistem pengendalian internal yang dapat diterapkan secara efektif, yang mencakup: Control Environment, Risk Assessment, Control Activities, Information \& Communication dan Monitoring Moeller (2009). 
Pengendalian internal yang lemah akan menyebabkan penyimpanganpenyimpangan. Hal ini dapat diamati dari berbagai media, seperti antara lain dimuat di Sindonews.com dengan topik Pengendalian intern buruk penyebab BUMN korup, dilansir oleh Forum Indonesia untuk Transparansi Anggaran (FITRA). FITRA memaparkan BUMN dinilai sebagai sarang korupsi yang merugikan negara dikarenakan pengendalian intern yang amburadul atau buruk. Kelemahan sistem pengendalian intern, terbagi menjadi tiga: (1) sistem pengendalian, akuntansi dan pelaporan, dimana pencatatan tidak akurat dan proses penyusunan laporan tidak sesuai ketentuan; (2) Kelemahan struktur pengendalian intern juga berpengaruh terhadap penyelenggaraan BUMN; $\quad$ (3) Tidak memiliki SOP yang formal, tidak ada pemisahan tugas dan fungsi yang memadai.

Banyak kasus-kasus perusahaan raksasa antara lain seperti Enron, Phar-Mor, Grazy Eddie dan lain sebagainya yang kolaps disebabkan lemah atau buruknya pengendalian internal (Cunningham \& Harris, 2006). Dalam disertasi dengan judul Internal Control, Enterprise Risk Management, and Firm Performance (Tseng, 2007) menunjukkan bahwa pengendalian internal yang lemah memiliki market-value yang rendah dan pengendalian internal yang lebih baik berarti kinerja perusahaan lebih baik juga.

Long (2009) dalam tulisan berjudul "Internal Control for Small Businesses to Reduce the Risk Fraud" memaparkan bahwa kebanyakan bisnis yang berkembang harus menangkal berbagai macam ancaman: persaingan, perubahan ekonomi, dan meningkatnya biaya barang atau sumber daya manusia-dan seterusnya. Satu jenis ancaman besar bagi bisnis yakni kecurangan (fraud). Kecurangan datang dalam berbagai bentuk, seperti kecurangan kartu kredit dan cek serta pencurian karyawan. Beberapa jenis yang paling umum dari kecurangan karyawan termasuk mencuri aset baik secara langsung maupun melalui kecurangan skema penagihan. Beberapa contoh khusus meliputi: membayar vendor fiktif, menggelapkan uang, mengklaim lembur yang tidak semestinya, mencuri persediaan, atau mengelembungkan rekening pengeluaran.

Banyaknya temuan kecurangan pada profesi akuntansi global yang merugikan stakeholder-terutama sejak kasus Enron, Worldcom, Xerox, Tyco, Global Crossing dan lainnya di tahun 2000 - dan dengan diterapkannya Sarbanes-Oxley Act menuntut pengendalian internal untuk menyajikan keyakinan yang memadai yang benar-benar mencerminkan adanya proses untuk menjaga aset perusahaan, menyajikan informasi yang diandalkan dan akurat, mendukung dan meningkatkan efisiensi operasional, dan mendorong keselarasan dengan kebijakan manajemen. Model COSO diterima sebagai sistem pengendalian internal yang selaras dengan Sarbanes-Oxley Act.

Sejumlah kerangka acuan pengendalian telah dikembangkan untuk membantu perusahaan dalam menciptakan sistem pengendalian internal yang baik, diantaranya COSO Internal Control Framework dan COSO Enterprise Risk Management. Saat ini 
terdapat tiga model kerangka kerja (framework) yang dikenal dalam kalangan praktisi atau profesional yakni (1) COSO yang ditetapkan pada tahun 1992, (2) GoCo (Guidance on Control) framework yang ditetapkan pada tahun 1995 oleh Canadian Institute of Chartered Accountants (CICA), dan (3) Internal Control: Rivised Guide for Directors on the Combined Code (dikenal dengan Turnbull Report), ditetapkan oleh Financial Reporting Council pada tahun 1999 dan diupdate lagi pada tahun 2005. Selain itu, juga terdapat COBIT (Control Objectives for Information and Related Technology) sebagai tehnologi informasi atas kerangka kerja pengendalian internal yang dikeluarkan oleh IT Governance Institute (Reding et al., 2009).

Berbagai penelitian empiris telah dilaksanakan untuk mengetahui pentingnya pengendalian internal COSO dalam menunjang pengendalian pada semua lini organisasi dalam organisasi apapun, seperti antara lain: (Tommie Singleton, 2002), (Long, 2009), (Olach \& Weeramantri, 2009), (Brown, Pott, \& Wömpener, 2008), (Schneider \& Becker, 2011), (Laine, Marscholl, Ngoc, \& Osche, 2013), (Hermanson, Smith, \& Stephens, 2012).

\section{TINJAUAN PUSTAKA}

\section{Landasan Teori}

Definisi pengendalian internal menurut Institute of Internal Auditors (IIA) bagi International Standards for Practice of Internal Auditing, sebagai:

Any action taken by management, the board, and other parties to manage risk and increase the likelihood that establish objectives and goods will be achieved. Management plans, organizes, and directs the performance of sufficient actions to provide reasonable assurance that objectives and goals will be achieved.

Definisi awal pengendalian internal yang dijabarkan oleh American Institute of Certifield Public Accountant (AICPA) atas Statement on Auditing Standards (SAS No. 1) adalah:

"Internal control comprises the plan of organization and all of the coordinate methods and measures adopted within a business to safeguard its assets, check the accuracy and reliability of its accounting data, promote operational efficiency, and encourage adherence to prescribed managerial policies".

COSO mendefinisikan pengendalian internal Moeller (2009, p. 32) sebagai:

"Internal control is a process, effected by an entity's board of directors, management and other personnel, designed to provide reasonable assurance regarding the achievement of objectives in the following categories:

- Effectiveness and efficiency of operations

- Reliability of financial reporting 
- Compliance with applicable laws and regulations."

\section{Tujuan Internal Control}

Arens, Elder, and Beasley (2012, p. 291) mengemukakan tujuan pengendalian internal sebagai berikut:

"Management typically has three broad objectives in designing an effective internal control system:

1. Reliability of financial reporting

2. Efficiency and effectiveness of operations

3. Compliance with applicable laws and regulations"

Moeller (2004, pp. 103-104) menyatakan pengendalian internal memiliki 4 tujuan (objective) yaitu:

1. Operations are Effective and Efficient

2. Compliance with Laws and Regulation

3. Financial and Management Reporting-Reliable

4. Safeguard Assets

\section{Komponen Pengendalian Internal COSO}

Pengendalian internal coso merupakan suatu sistem yang terdiri atas komponen-komponen sub-sistem yang saling berhubungan dan saling ketergantungan bahkan mungkin saja dapat mempengaruhi satu dengan yang lainnya. Setiap komponen mengandung banyak pengendalian, dirancang dan diimplementasikan oleh manajemen untuk memberikan kepastian yang layak bahwa tujuan pengendaliannya akan tercapai. Arens et al. (2012, p. 295), Reding et al. (2009, pp. 6-10-616) dan Moeller (2009, p. 33) mengemukakan bahwa:

The COSO internal control components include the following:

1. Control environment

2. Risk assessment

3. Control activities

4. Information and communication

5. Monitoring

\section{Penelitian bagi organisasi yang belum menerapkan Model COSO}

Penelitian Olach and Weeramantri (2009) dengan judul How COSO has Improved Internal Control in The United States, ditujukan bagi organisasi-organisasi di Negara lain dan Amerika Serikat yang masih belum menerapkan framework COSO mungkin dapat membawa manfaat bagi organisasinya.

Olach and Weeramantri (2009) memaparkan hasilnya bahwa organisasi yang memanfaatkan framework COSO, telah dapat mengurangi biaya berlebihan sesuai yang diharapkan Sarbanes-Oxley. Kerangka COSO memenuhi kriteria dan dapat digunakan 
sebagai framework untuk kebutuhan evaluasi pengendalian internal manajemen tahunan.

Disimpulkan Olach dan Weeramantri bahwa lebih dari 20 tahun, COSO telah membantu menciptakan pola pikir yang berorientasi kontrol bagi manajer dan auditor internal sehingga risiko dan masalah pengendalian dapat dilihat secara konsisten, baik secara internal maupun eksternal. Tidak ada kerangka kerja pengendalian internal dianggap sebagai "satu ukuran cocok untuk semua" solusi. Namun, melihat kontribusi COSO dari waktu ke waktu memberikan auditor dan manajer bagaimana menggunakan pendekatan ini dalam menilai risiko dan pengendalian internal. Konsekuensinya, risiko dapat dikurangi ke tingkat yang memungkinkan organisasi untuk mencapai tujuan dan sasarannya.

Penelitian Olach dan Weeramantri (2009) ini, menekankan kerangka COSO yang telah berkembang dari waktu ke waktu, memberikan kontribusi bagi organisasiorganisasi yang telah menerapkan atau menggunakan kerangka coso sebagai pengendalian internal. Bagi organisasi-organisasi yang belum menerapkan kerangka COSO dapat mempertimbangkan untuk penerapannya.

Penelitian Schneider and Becker (2011) dengan judul Using the COSO model of Internal Control as a Framework for ethics initiatives in business schools juga dimaksudkan agar dapat menggunakan sebuah kerangka kerja komprehensif untuk pemantauan, evaluasi, perbaikan/peningkatan etika pendidikan dalam program bisnis. Model yang diajukan didasarkan pada pengendalian internal framework cOSO yang sudah diterima secara luas oleh praktisi akuntansi di Amerika Serikat. Pemaparan diakhiri dengan rekomendasi untuk menggunakan kerangka kerja coSO dalam memandu pengembangan etika oleh institusi sekolah dan dievaluasi oleh lembaga akreditasi (using cOSO framework to guide the development of ethics initiatives by business schools and to the evaluation of such initiatives by accreditation agencies).

Penelitian Sutariono (2013) judul Analisis Pencegahan dan Pendeteksian RisikoRisiko Operasional Perusahaan berdasarkan COSO Internal Control Integrated Framework (Studi Kasus PT. XYZ dimaksudkan untuk mengetahui risiko-risiko operasional di dalam perusahaan serta bagaimana tindakan preventif dan detektif perusahaan terhadap risiko-risiko tersebut berdasarkan aspek atau elemen pengendalian internal yang diterbitkan oleh COSO.

Sutariono (2013) menganalisis kelima komponen pengendalian internal cOSO Internal Control Integrated Framework meliputi lingkungan pengendalian (control environment), penaksiran risiko (risk assessment), aktivitas pengendalian (control activities), pemrosesan informasi dan komunikasi (information processing and communication), dan pemantauan (monitoring). Kelima komponen pengendalian 
internal tersebut dianalisis berdasarkan data empiris dari identifikasi risiko-risiko operasional di PT XYZ. Hasilnya, PT XYZ memiliki risiko-risiko operasional yang cukup signifikan dan dapat mempengaruhi kinerja perusahaan. Kelemahan pada sistem pengendalian internal yang diterapkan oleh unit manajemen menjadi faktor utamanya.

Sutariono tidak menemukan tindakan preventif dan detektif yang memadai di PT XYZ guna menunjang pelaksanaan pengendalian internal perusahaan. Hal ini menunjukkan belum diterapkan suatu sistem pengendalian seperti framework COSO sebagai suatu kerangka untuk melakukan pengendalian atas risiko-risiko operasional perusahaan yang ada.

Penelitian lain yang dilakukan oleh Lakis and Giri nas (2012) dengan judul The Concept Of Internal control system: Theoretical Aspect, melakukan analisis konsep sistem pengendalian internal yang melibatkan analisis hasil ilmiah terbaru dari konsep sistem pengendalian internal yang memenuhi kondisi bisnis modern.

Hasil dari penelitian Lakis dan Giri menyajikan generalisasi inklusif dan definisi pengendalian internal bahwa: sistem pengendalian internal merupakan bagian dari sistem manajemen perusahaan untuk memastikan pelaksanaan tujuan perusahaan itu, kinerja komersial-ekonomi yang efektif, ketaatan prinsip akuntansi dan kontrol yang efektif atas risiko kerja, aktif meminimalkan jumlah kesalahan yang disengaja dan tidak disengaja, dan untuk menghindari penipuan dalam proses kinerja perusahaan yang dibuat oleh otoritas atau karyawannya.

\section{Penelitian bagi organisasi yang telah menerapkan Model coso}

Penelitian T Singleton (2007) dalam Information System Control Journal Volume 6, 2007 dengan judul The COSO Model: How IT Auditors Can Use It to Evaluate the Effectiveness of Internal Control, memaparkan penerapan control melalui sistem komputer (sistem informasi) dan teknologi informasi harus mampu mendeteksi pernyataan yang salah atau kesalahan-kesalahan yang terjadi.

Penelitian Singleton (2007) melihat dari sisi penggunaan teknologi informasi untuk menilai efektivitas pengendalian internal suatu organisasi yang telah menggunakan teknologi informasi pada aktivitas operasional perusahaan.

Firnanda (2013) melakukan penelitian dengan judul: Sistem Pengendalian Internal Atas Siklus Pendapatan (Studi Kasus pada CV. Sinar Terang Distributor). Firnanda melaksanakan penelitian untuk mengidentifikasi dan menganalisa sistem pengendalian internal atas siklus pendapatan pada CV. Sinar Terang Distributor, dan juga untuk mengetahui kendala yang dihadapi oleh perusahaan dalam menerapkan pengendalian internal dengan menggunakan kerangka cOSO.

Hasil penelitian Firnanda bahwa pelaksanaan sistem pengendalian internal sesuai kerangka COSO sangat lemah, berarti perusahan belum menerapkan framework coso sebagaimana mestinya, sehingga kelima komponen yang dianalisis menunjukkan 
kelemahan tiap komponen. Komitmen pimpinan perusahaan akan sangat mendukung dalam penerapan dan pelaksanaan pengendalian internal.

\section{METODE PENELITIAN}

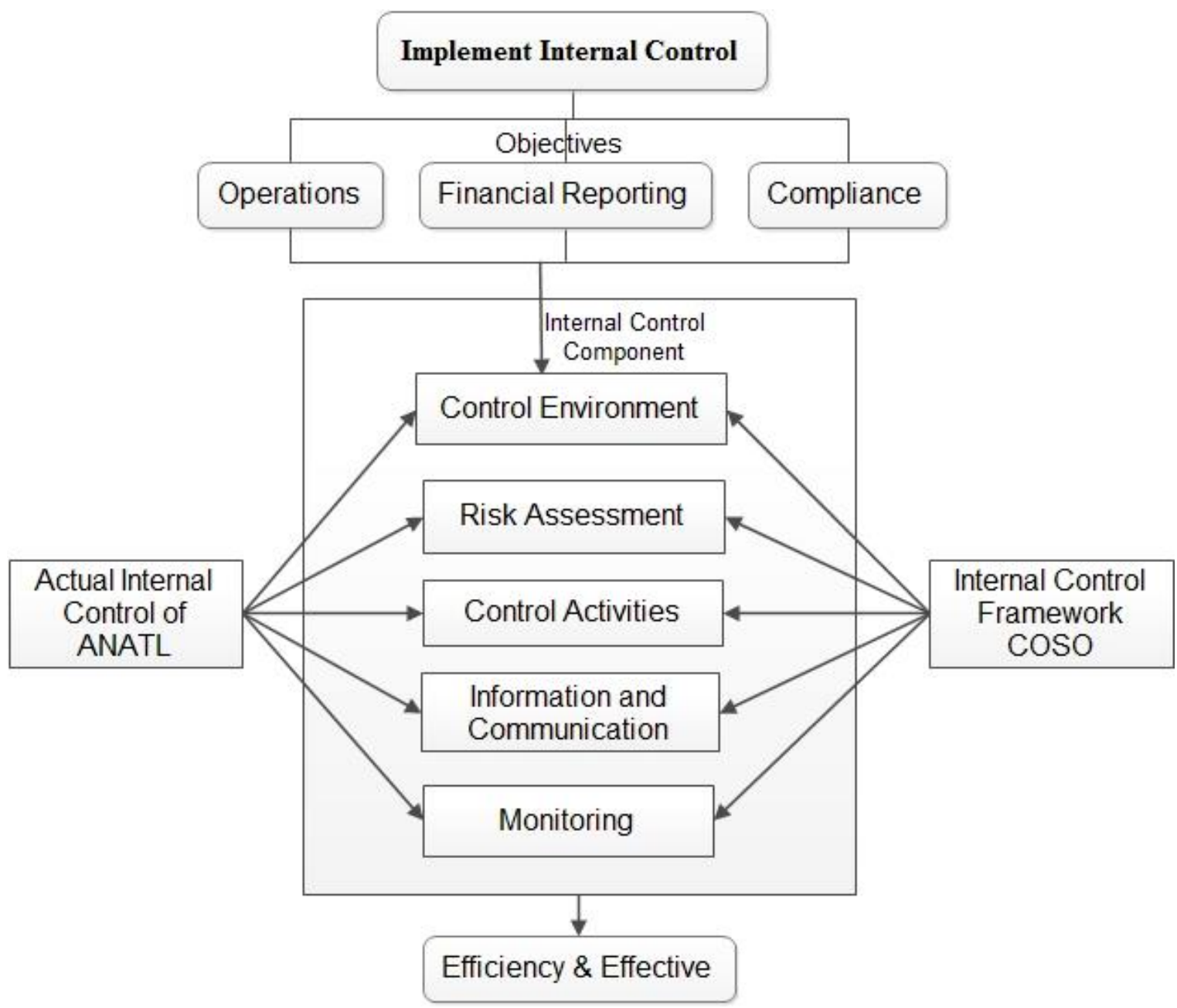

Gambar 1. Kerangka Pemikiran

Pelaksanaan pengendalian internal merupakan tanggung jawab manajemen agency ANATL. Penulis ingin menganalisa kondisi pengendalian internal aktual yang dilaksanakan pada agency ANATL dan dibandingkan dengan framework COSO dalam rangka pencapaian tujuan operation, financial reporting dan compliance. Untuk mencapai tiga tujuan utama harus didukung dengan komponen-komponenen pengendalian internal: control environments, risk asessement, control activities, information and communication, dan monitoring. 
Defisiensi-defisiensi yang ada disarankan untuk dilakukan perbaikan pengendalian internal (improvement internal control as COSO framework order) pada agency ANATL sesuai prinsip-prinsip atau komponen COSO. Apabila framework COSO diimplementasikan secara utuh, maka proses kegiatan agency ANATL akan efisien dan efektif.

\section{Teknik Analisis}

Penelitian ini dibagi dalam dua tahap sebagaimana telah dikemukakan diatas, sehinga teknik analisis data dilakukan sebagai berikut:

\section{Tahap I: Evaluasi}

Evaluasi dilakukan dengan tipe teknik query wawancara: merupakan suatu analisis yang dilakukan dengan menanyai pejabat/pegawai berkompoten, berdasarkan pertanyaanpertanyaan yang telah disiapkan.

\section{Tahap 2: Pelaksanaan penelitian}

Yin (2012) menyatakan setiap penelitian mempunyai desain penelitian, yang merupakan kaitan logis antara data empiris dengan pertanyaan awal penelitian. Dalam bahasa sehari-hari, desain penelitian adalah suatu rencana tindakan untuk berangkat dari sini ke sana, dimana "disini" bisa diartikan sebagai rangkaian pertanyaan awal yang harus dijawab, dan "di sana" merupakan serangkaian konklusi tentang pertanyaan-pertanyaan yang ada. Berdasarkan konsep diatas desain penelitian adalah:

Table 1

\begin{tabular}{|c|c|c|c|c|c|}
\hline Question & Proposition & $\begin{array}{c}\text { Unit of } \\
\text { Analysi } \\
\mathrm{s}\end{array}$ & $\begin{array}{c}\text { Data } \\
\text { collected }\end{array}$ & $\begin{array}{c}\text { Data } \\
\text { collection } \\
\text { method }\end{array}$ & $\begin{array}{c}\text { Criteria to } \\
\text { interpret } \\
\text { finding }\end{array}$ \\
\hline
\end{tabular}


Verissimo Nai Sia

\begin{tabular}{|c|c|c|c|c|c|c|}
\hline $\begin{array}{l}\text { Unt } \\
\text { uk } \\
\text { tek } \\
\text { nik } \\
\text { anal } \\
\text { isis }\end{array}$ & $\begin{array}{l}\text { Bagaimana } \\
\text { komitmen } \\
\text { agency dalam } \\
\text { menerapkan } \\
\text { pengendalian } \\
\text { internal }\end{array}$ & $\begin{array}{l}\text { Implementasi } \\
\text { pengendalian } \\
\text { internal secara utuh } \\
\text { maka kinerja } \\
\text { agency ANATL akan } \\
\text { sangat baik. }\end{array}$ & $\begin{array}{l}\text { Agency } \\
\text { ANATL }\end{array}$ & $\begin{array}{l}\text { Laporan, } \\
\text { SOP dan } \\
\text { data-data } \\
\text { lain yang } \\
\text { berkaitan } \\
\text { pelakasana } \\
\text { an internal } \\
\text { control } \\
\end{array}$ & $\begin{array}{l}\text { Wawancara } \\
\text { Observasi } \\
\text { Observasi } \\
\text { Partisan }\end{array}$ & $\begin{array}{l}\text { Baik atau } \\
\text { Buruk } \\
\text { atau } \\
\text { Memadai atau } \\
\text { Lemah }\end{array}$ \\
\hline $\begin{array}{l}\text { nya, } \\
\text { pen } \\
\text { ulis } \\
\text { me } \\
\text { ngg }\end{array}$ & $\begin{array}{l}\text { Bagaimana } \\
\text { kualitas } \\
\text { pengendalian } \\
\text { internal } \\
\text { agency } \\
\text { ANATL? }\end{array}$ & $\begin{array}{l}\text { Semakin baik } \\
\text { kualitas } \\
\text { pengendalian } \\
\text { internal, semakin } \\
\text { kecil resiko yang } \\
\text { timbul dan } \\
\text { kecurangan dapat } \\
\text { dicegah }\end{array}$ & $\begin{array}{l}\text { Agency } \\
\text { ANATL }\end{array}$ & $\begin{array}{l}\text { Aturan- } \\
\text { aturan, } \\
\text { Kebijakan } \\
\text { yang telah } \\
\text { berlaku }\end{array}$ & $\begin{array}{l}\text { Rekam Arsip } \\
\text { Wawancara }\end{array}$ & $\begin{array}{l}\text { Memadai atau } \\
\text { Lemah }\end{array}$ \\
\hline
\end{tabular}

kan Memo analitis yang menautkan data konkret atau bukti baku untuk pemikiran abstrak dan teoretis berisi refleksi pemikiran data dan coding (Neuman, 2013) yang ditunjukkan dalam gambar di bawah:

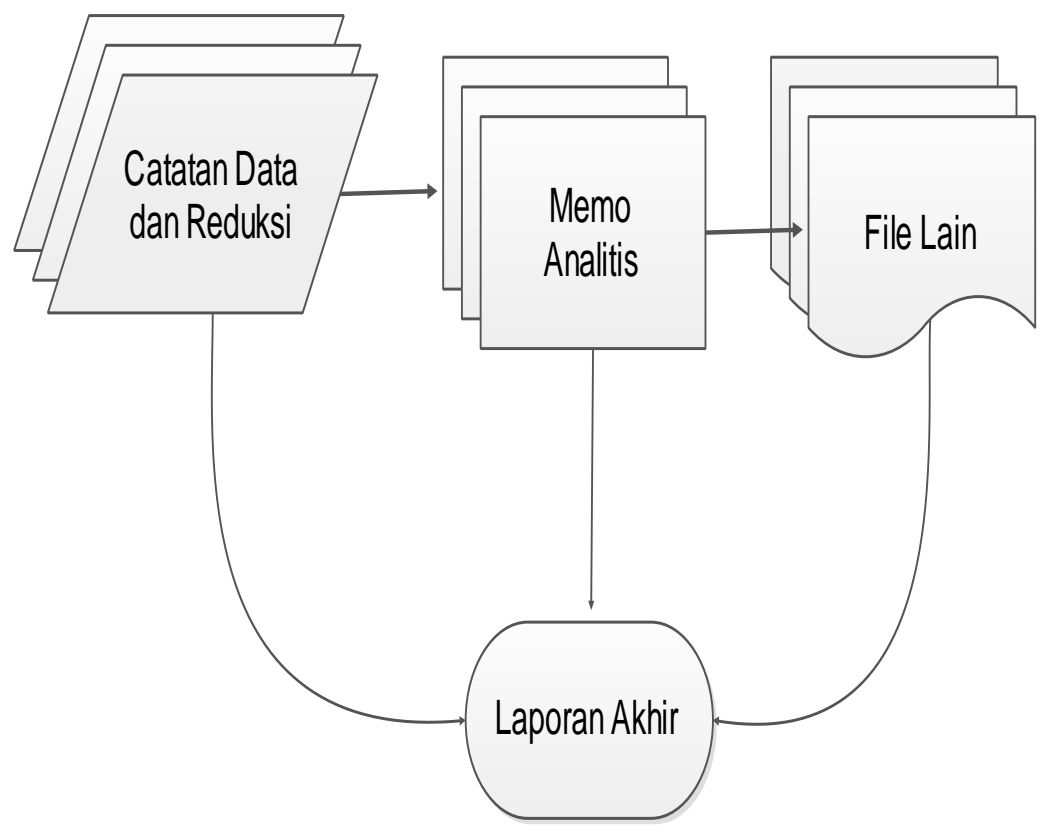

Gambar 2. Memo Analitis dan File Lain

Sumber:. Neuman, 2013, hal 568 
Catatan data lapangan direduksi, dirangkum, dan kemudian dipilah-pilah hal yang pokok, dipilih yang terpenting. Memo analitis dimaksudkan agar lebih mempermudah bagi peneliti untuk dapat melihat gambaran secara keseluruhan atau bagian-bagian tertentu dari data penelitian.

Data memo dihubungkan dengan file-file lain sesuai permasalahan yang dihadapi. Dari catatan data, kemudian dilakukan reduksi selanjutnya dianalisis dalam suatu memo yang didukung dengan file-file lain, penulis dapat menyusun laporan setelah mengumpulkan data dari lapangan. Gambar 2 merupakan proses interaksi antara komponen analisis dengan pengumpulan data, dan merupakan suatu proses siklus sampai dengan aktivitas penelitian selesai.

\section{HASIL PENELITIAN DAN ANALISA}

Implementasi Pengendalian internal di Agency ANATL dibandingkan dengan kerangka coso?

\section{Ditinjau dari kategori kerangka COSO}

Operating Category

Salah satu tujuan yang hendak dicapai dalam pengendalian internal kerangka cOSO adalah kegiatan operasional yang efektif dan efisien (effectiveness and efficiency of operations), Moeller (2009, p. 32).

Rekaman arsip menunjukkan bahwa aktivitas operasional adalah tugas dan fungsi yang berhubungan dengan operasi bandara Dili bagi airline, operators, agents, dan contractors sesuai prosedur dan manual yang ada. Penanggungjawab aktivitas operasional adalah Airport Manager, Chief Airport Operation dan Duty Airport Operations Officer.

Aktivitas operasional bandar udara merupakan satu sistem karena terdiri atas komponen-komponen yang berinteraksi satu dengan lainnya dan menghasilkan satu keluaran (output). Ada berbagai kegiatan yang saling berkaitan dalam suatu operasional bandara yang menentukan kinerja bandara dalam mewujudkan on time performance pesawat udara, salah satunya adalah kegiatan pelayanan Ground Handling.

Kegiatan utama Ground Handling di Airside (Ramp Operations) memberikan pelayanan berupa GSE (Ground Support Equipment) dengan jumlah dan jenis sesuai kebutuhan dan tipe pesawatnya. Secara operasional, kegiatan ground handling dibedakan menjadi dua bagian, yaitu pelayanang round handling di Terminal (Terminal Operations) dan di Airside (Ramp Operations).

Pelaksanaan operasional di lingkungan agency ANATL telah berjalan dengan baik sesuai standard operasi prosedur (SOP) dan manual yang diadopsi dari standar ICAO. Standar ini diadopsi dan diimplementasi secara utuh.

Perbedaan interpretasi inter-intansi (CIQ) dipandu oleh Airport Manager, dapat dikoordinasikan dengan masing-masing instansi yang ada. 


\section{Financing Reporting Category}

Penerimaan pendapatan Bandara Dili bersumber dari penerapan tarif-tarif yang ada, dikelompokkan menjadi tiga bagian yakni yang bersumber dari Landing Fee (pendaratan pesawat), Airport Tax (jasa pelayanan penumpang) dan Rental Charges (sewa ruang dan tanah). Dari tiga kelompok ini dikategorikan sebagai penerimaan jasa pelayanan aeronautical adalah Landing fee dan Airport tax sedangkan rental charges merupakan penerimaan jasa non aeronautical.

Hasil penelaahan dokumen disimpulkan bahwa tarif-tarif tersebut diatas, baru diterapkan $30 \%$, yang merupakan penerapan tarif warisan regulasi UNTAET no 6 tahun 2000. Laporan pungutan atau tagihan masih berpedoman pada Peraturan No. 1 Tahun 2003 dimana telah ditetapkan Policy \& Procedures Manual for Revenue Recognition dimana telah ditentukan pengendalian internal.

Untuk pengeluaran anggaran/pembiayaan masih sepenuhnya mengikuti aturanaturan atau regulasi yang dikeluarkan oleh Kementerian Keuangan Negara Timor-Leste. Rancangan Anggaran Pendapatan dan Belanja belum disesuaikan dengan Undang Undang No. 14/2003 dan Peraturan Pemerintah no. 8/2005 tentang pembentukan perusahaan negara (BUMN).

Penelusuran dokumen yang ada menunjukkan laporan penerimaan dan pengeluaran dibuat untuk dilaporkan secara hirarkia per triwulan, sedangkan laporan bulanan ditujukan kepada Kementerian Keuangan Negara Timor-Leste.

\section{Compliance Category}

Kepatuhan terhadap hukum dan peraturan-peraturan yang telah ditetapkan merupakan tujuan yang hendak dicapai dalam konsep pengendalian internal kerangka coso Moeller (2009, p. 32).

peraturan diterapkan oleh ANATL sesuai dengan Standar dan Rekomendasi Praktik yang ditetapkan oleh Organisasi Penerbangan Sipil Internasional (ICAO). Hukum dan aturan penerbangan telah dihasilkan semenjak pasca restorasi kemerdekaan (jaman UNTAET) dan setelah restorasi kemerdekaaan.

Rekaman arsip dokumen menunjukkan Peraturan-Peraturan yang telah ditetapkan tetapi belum diimpelemtasikan, yakni:

1. Peraturan Pemerintah No. 3/2006 tentang Rejim penguasaan ruang dan lahan di Bandara. Sebagai Perusahaan Umum Administrasi Bandara dan Navigasi Udara Timor-Leste memiliki otonomi keuangan dan administrasi sendiri, untuk eksplorasi perusahaan publik dan pembangunan infrastruktur bandara.

2. Peraturan Pemerintah No.5/2006 tentang Aturan Sertifikasi Operator Penerbangan. Kegiatan operator transportasi udara adalah bisnis yang sangat penting bagi Timor-Leste, tidak hanya untuk merangsang investasi swasta tetapi terutama untuk membawa manfaat bagi pembangunan ekonomi dan sosial negara.

3. Peraturan Pemerintah No.3/2006 yaitu Aturan penetapan tarif-tarif kebandaraan untuk mengganti regulasi UNTAET. 
4. Peraturan Pemerintah No. 4/2013 tentang Susunan, tugas dan tanggung jawab Kementerian Transportasi dan Telekomunikasi, dalam pasal 20 didefinisikan ANATEL-EP adalah perusahaan publik yang memiliki misi menyelenggarakan manajemen dan administrasi bandara nasional dalam segala aspeknya.

Tim Audit ICAO Universal Safety Oversight Audit Programme (USOAP) telah memberikan komentar bahwa: "UU Nomor 8/2005, pembentukan Navigasi Udara dan Bandara Timor-Leste (ANATL) sebagai services provider atau layanan milik negara. Namun, belum diimplementasikan UU tersebut oleh Pemerintah TimorLeste. Tim audit ICAO telah membuat 54 temuan dalam 7 bidang dan mengeluarkan rekomendasi atas hasil temuan audit. Temuan dan rekomendasi tim audit ICAO telah diterima dan diakui oleh ANATL.

Audit Kepatuhan yang dilakukan oleh Dewan Audit (Câmara de Contas, Tribunal de Recurco) dalam laporan (Relatório) No. 01/VIL/2014/CC memberi rekomendasi untuk:

a. Dilakukan segera langkah-langkah yang diperlukan untuk memastikan bahwa ANATL dibentuk dan berfungsi sesuai dengan UU no. 8/2005 dan Peraturan Pemerintah yang telah ditetapkan.

b. Dilakukan langkah-langkah mendesak yang diperlukan sehingga ANATL dipisahkan dari badan (AACTL) yang menjalankan kontrol atas bandara.

Sesuai UU No. 8/2005 bahwa Kementerian Perhubungan dan Telekomunikasi dan Kementerian Keuangan (pasal 4 dan pasal 24-25) bertugas menetapkan aturan-aturan tentang manajemen ekonomi dan keuangan (gestão económia e financeira) untuk pelaksanaan UU dimaksud. Dengan demikian Kementerian terkait harus menetapkan peraturan pelaksana dalam rangka menjabarkan UU yang ada.

Dari uraian diatas dapat disimpulkan bahwa kepatuhan terhadap hukum dan aturan-aturan yang ada sangat lemah, sehingga dapat menyebabkan penyimpangan-penyimpangan. Hal ini tercermin dari tidak patuh pada SOP, tidak memberikan pelayanan kepada pesawat Airnorth yang terbang kembali ke Darwin, pegawai yang bolos setelah pesawat take off, dan tindakan-tindakan lain.

\section{Ditinjau dari Komponen-komponen kerangka COSO}

Lima komponen pengendalian internal kerangka COSO yang dijabarkan dalam 17 unsur diedarkan kepada 6 orang yakni Direktur dan para Manajer, dikembalikan 5. Jawaban yang diperoleh beragam, setelah dilakukan crosscheck melalui observasi dan wawancara menunjukkan realitas yang berbeda. Dari 17 unsur, hanya 9 unsur yang telah diterapkan, namun penerapannya tidak secara utuh. Dengan demikian dapat disimpulkan bahwa penerapan pengendalian internal pada agency ANATL sangat lemah.

Komponen-komponen pengendalian internal sesuai kerangka COSO dapat dijelaskan di bawah ini.

\section{Pengendalian Lingkungan (Control Environment's)}

Lingkungan pengendalian (control environment) sesuai kerangka COSO, terkait dengan: integritas dan nilai etika; komitmen terhadap kompetensi; filosofi manajemen dan gaya operasi; struktur organisasi; penetapan otoritas dan tanggung jawab; kebijakan dan praktik sumber daya manusia (Moeller, 2009, pp. 33-38). 


\section{Integritas dan nilai etika}

Integritas dan nilai etika merupakan standar perilaku yang berlaku di suatu perusahaan. Integritas dan nilai etika meliputi tindakan manajemen untuk menghilangkan atau mengurangi motif yang menyebabkan pegawai tidak jujur, melanggar hukum, ataupun bersikap tidak etis. Manajemen harus mempunyai komitmen atau political will untuk melaksanakan kebijakan secara konsisten yang mendorong kegiatan operasional menjadi lebih efektif dan efesien, mengingat aktivitas di bandara berhubungan dengan pegawai, mitra kerja, pelanggan, masyarakat, pemerintah dan stakehoulders lainnya juga memiliki standar etika yang harus diperhatikan.

\section{Komitmen terhadap kompetensi}

Komitmen terhadap kompetensi mencakup pertimbangan manajemen terhadap tingkat kompetensi untuk suatu pekerjaan dan bagaimana tingkatan tersebut diubah menjadi keterampilan dan pengetahuan yang dibutuhkan, misalkan pertimbangan manajemen terhadap tingkat kompetensi dari pekerjaan tertentu dan menetapkannya dalam bentuk persyaratan yang harus dipenuhi.

Semenjak awal ANATL telah dihadapkan pada persoalan kompetensi yaitu pengetahuan dan ketrampilan yang diperlukan untuk menyelesaikan tugas-tugas. Kompetensi karyawan yang ada memiliki skills atau latar belakang pendidikan yang tidak berkaitan dengan dunia penerbangan. Hasil diskusi dengan Manager ATS, seorang yang memiliki latar belakang penerbangan, bahwa jumlah karyawan dengan background dunia penerbangan \pm 20 orang. Hal ini juga diungkapkan Arruda (2005, p. 61) bahwa ANA Consórcio mengalami kesulitan besar dalam hal rekrutmen, padahal misinya di Timor adalah perekrutan dan pelatihan personil yang bertanggung jawab mengoperasikan bandara Dili-Comoro setelah kemerdekaan Timor-Leste. (Missão em Timor o recrutamento e formação de efectivos locais, com a finalidade de os mesmos assumirem funções $e$ responsabillidades no future funcionamento do aeroporto de Dili-Comoro, tinhamos sentido desde o início grandes deficuldades).

\section{Filosofi manajemen dan gaya operasi}

Filosofi manajemen dan gaya operasi ditandai adanya tata tertib perusahaan, kebijakan perusahaan, Standar Operasional Procedur dan anggaran untuk mengatur kegiatan operasi perusahaan. Tentu gambaran dari filosofi manajemen dan gaya operasi akan tercermin pada "tindakan lebih berguna daripada katakata".

ANATL telah mempraktekkan filosofi dan gaya operasi yang menjamin operasional bandara. Hal ini nampak pada penetapan karyawan duty ship dan pihak manajemen selalu menekankan untuk patuh pada SOP yang ada.

\section{Struktur organisasi}

Struktur organisasi perusahaan menunjukkan tanggung jawab dan wewenang yang ada, juga menghubungkan garis arus komunikasi. Struktur organisasi 
menggambarkan manejemen dan elemen fungsional perusahaan serta bagainana kebijakan dan prosedur berhubungan dengan pengendalian.

Dewan Komisaris (Conçelho Administração) menetapkan struktur organisasi yang menunjukkan garis pelaporan, serta wewenang dan tanggung jawab dalam mencapai tujuan organisasi. Struktur organisasi ANATL belum diisi sesuai UU No. 8/2005 tentang pembentukan perusahaan negara atau BUMN.

\section{Penetapan otoritas dan tanggung jawab}

Pembagian wewenang dan tanggung jawab dituliskan dalam job descriptions. Uraian tugas memperjelas struktur organisasi sehingga setiap personil dapat mengetahui wewenang dan tanggung jawab yang diberikan kepadanya. Metode komunikasi formal mengenai wewenang dan tanggungjawab dan masalah sejenis yang berkaitan dengan pengendalian.

Secara macro ANATL belum memperoleh delegasi wewenang dan tanggung jawab sesuai UU dan Peraturan yang ada yakni belum dilakukan pemisahan tugas dan wewenang antara regulator dan services provider.

\section{Kebijakan dan praktik sumber daya manusia}

Aspek paling penting dalam sistem pengendalian internal adalah pegawai. Orang yang jujur dan efisien akan dapat bekerja pada tingkat yang tinggi dengan sedikit pengendalian. Meskipun banyak pengendalian, orang yang tidak jujur dan tidak kompeten dapat mengacaukan sistem. Meskipun pegawai tersebut kompeten dan terpercaya, setiap orang memiliki kelemahan yang melekat. Meraka dapat menjadi bosan atau tidak puas, masalah pribadi dapat merusak kinerjanya.

Pengembangan SDM dalam penerbangan sipil penting. Sebagaimana ditekankan oleh ICAO, SDM merupakan salah satu aspek utama pendukung keselamatan penerbangan dan pembangunan transportasi udara berkelanjutan. ANATL mengupayakan untuk merekrut individu-individu yang berkompoten dalam memberikan pelayanan jasa (services provider).

Lingkungan pengendalian menurut kerangka COSO merupakan fondasi dalam menopang komponen-komponen pengendalian internal lainnya. Lingkungan pengendalian yang lemah pada agency ANATL akan mempengaruhi kinerja sebagaimana yang diharapkan pelanggan yaitu penumpang, operator penerbangan, pihak-pihak lain yang terkait dengan penerbangan, dan pemerintah (stakeholder).

\section{Penilaian Risiko (Risk Assessment)}

Konsep kerangka COSO dalam penilaian risiko (risk assesment), terkait dengan: penilaian risiko; identifikasi risiko; analisa risiko; dan pengelolaan risiko.

Dalam rekaman arsip dokumen "Aerodrome Manual International Airport Presidente Nicolau Lobato", risiko telah didefinisikan sesuai dengan kerangka coso yaitu:

1. Risiko, sesuatu perubahan yang terjadi yang akan berdampak pada tujuan. Hal ini diukur didalam item konsekuensi dan kemungkinan (Risk; the change of something happening that will have an impact upon objectives. It is measured in items of consequences and likelihood). 
2. Analisis risiko: Penggunaan informasi sistematis yang tersedia untuk menentukan seberapa sering peristiwa tertentu dapat terjadi dan besarnya konsekuensi tersebut (Risk analysis: A systematic use of available information to determine how often specified events may occur and the magnitude of their consequences).

3. Penilaian risiko; keseluruhan proses analisis risiko dan evaluasi risiko (Risk assessment; the overall process of risk analysis and risk evaluation).

4. Evaluasi Risiko; proses yang digunakan untuk menentukan prioritas manajemen risiko dengan membandingkan tingkat risiko terhadap standar yang telah ditentukan, target tingkat risiko atau kriteria lain (Risk Evaluation; the process used to determine risk management priorities by comparing the level of risk against predetermined standards, target risk levels or other criteria).

5. Identifikasi risiko; proses penentuan apa yang bisa terjadi, mengapa, dan bagaimana (Risk identification; the process of determining what can happen, why, and how).

6. Tingkat risiko; tingkat risiko dihitung sebagai fungsi dari kemungkinan dan konsekuensi (Risk level; the risk level calculated as a function of likelihood and consequences).

7. Manajemen Risiko; Budaya, proses dan struktur yang diarahkan menuju manajemen yang efektif dari peluang potensial dan efek samping (Risk Management; The culture, process and structures that are directed towards the effective management of potential opportunities and adverse effects).

Tujuan yang dicapai ANATL sangat jelas yaitu menyelenggarakan suatu pelayanan jasa dengan mempertahankan keamanan dan kenyamanan konsumen. Adanya tujuan ini menyebabkan ANATL telah menetapkan aturan dan prosedur untuk mengindentifikasi risiko, menganalisisnya dan mengelola risiko yang timbul.

\section{Aktivitas Pengendalian (Control Activities)}

Aktivitas pengendalian (control activities) sesuai kerangka COSO, terkait dengan: kebijakan, prosedur, otorisasi, rekonsiliasi, review, pengamanan aset, pemisahan tugas dan penilaian kinerja.

\section{Kebijakan}

Aktivitas pengendalian adalah kebijakan dan prosedur yang membantu menjamin bahwa arahan manajemen dilaksanakan untuk pencapaian tujuan entitas ANATL. Chief Operations menyatakan bahwa kebijakan delegasi wewenang mengalami tumpang tindih, hal ini ditunjukkan dengan adanya perintah pada staf tidak melalui hirarki yang ada, sehingga melemahkan tanggung jawab.

\section{Prosedur}

ANATL memiliki prosedur tertulis berupa Standard Operational Prosedure (SOP) untuk mengatur kegiatan operasi di bandara. Setiap Bagian/Unit memilki SOP sesuai bidang atau jenis aktivitasnya. 
Jurnal Ekonomi dan Bisnis Airlangga, Vol. 29, No.2, June - November 2019

\section{Otorisasi}

Otorisasi adalah keputusan tentang kebijakan baik untuk transaksi yang bersifat umum maupun khusus. Otorisasi dapat berbentuk umum atau khusus. Otorisasi umum berarti bahwa manajemen menyusun kebijakan bagi organisasi untuk ditaati. Bawahan diinstruksikan untuk menerapkan otorisasi umum ini dengan cara menyetujui seluruh transaksi dalam batas yang ditentukan oleh kebijakan. Setiap transaksi harus diotorisasi secara memadai.

Observasi selama \pm 10 hari kerja pada beberapa counter antara lain Bagain Komersial, Penerbitan Acces Pass, penerimaan Airport Tax, penerimaan carter flight non schedule tidak dilakukan otorisasi atas transaksi yang terjadi.

Disimpulkan otorisasi tidak dilakukan karena belum ada kebijakan manajemen atas hal ini. Selain itu, belum ada pemisahan fungsi tugas yang jelas. Pemisahan ini diperlukan untuk mencegah orang yang menyetujui transaksi, memiliki kendali atas trasnsaksi tersebut. Misalkan: orang yang sama seharusnya tidak diizinkan menyetujui faktur tagihan (invoice) dan juga menandatangani pembayaran tagihan.

\section{Rekonsiliasi}

Rekaman dokumen menunjukkan rekonsiliasi terjadi pada transaksi dan saldo bank antara ANATL dengan para pelanggan (customers) dan bank BNU. Konfirmasi kepada Chief Administration and Finances bahwa rekonsiliasi bank dilakukan secara rutin setiap bulan, antara tanggal $1 \mathrm{~s} / \mathrm{d} 3$ awal bulan. Untuk rekonsiliasi transaksi dapat dilakukan setiap saat diperlukan antara ANATL dengan para pelanggan.

Rekonsiliasi juga terjadi data manifest passanger dan flight recorder antara bagian Komersial, Bagian Operasional dengan customers Ground Handling Services.

\section{Review terhadap performa operasi}

Ada mekanisme untuk meninjau dan mengevaluasi pelaksanaan operasional. Pada tahap ini dilakukan review atas program atau kegiatan-kegiatan dengan tujuan untuk mengevaluasi sejauh mana pencapaiaan sasaran secara efisien, dan efektif.

ANATL bergerak dalam bidang usaha jasa maka review atas performance selalu dilakukan untuk mengevaluasi pelayanan yang disediakan telah memuaskan customers dan review operasional adalah untuk peningkatan dan solusi praktis yang dapat diimplementasikan jajaran manajemen.

6. Keamanan terhadap Aset

Pelayanan jasa Bandara Dili harus didukung sarana dan prasarana atau aset-aset dalam rangka memberikan pelayanan kegiatan operasional dan komersial. Asetaset ANATL antara lain: runway, runway lights, taxiway, apron, radio komunikasi, pemadam kebakaran, tanah dan kendaraan. Selain aset-aset, kegiatan operasional juga harus didukung perlengkapan dan perlatan yang selalu tersedia. Selama \pm 12 hari observasi terhadap Gudang Office stationary and supply, disimpulkan bahwa pengamanan aset tidak dilakukan secara ketat. Personel yang 
menanggani pergudangan hanya 2 orang saja, sehingga pencatatam barang masuk dan keluar tidak dilakukan sesuai metode dan prosedur yang ditentukan.

\section{Pemisahan tugas}

Pemisahan tugas merupakan suatu prinsip dasar pengendalian internal yang mencegah individu-individu dari memiliki tanggung jawab untuk semua tahap dari suatu proses pekerjaan terhadap penyalahgunaan atau penyimpangan. Pembagian tugas adalah untuk memisahkan fungsi operasi dan penyimpanan dari fungsi akuntansi (pencatatan). Suatu fungsi tidak boleh melaksanakan semua tahap dalam suatu transaksi.

Pemisahan tugas di ANATL merupakan unsur yang paling lemah. Observasi di beberapa counter seperti bagian penyimpanan, penerimaan atas pembayaran jasa pelayanan penerbangan (airport tax), penerimaan pembayaran atas penerbitan acces pass, dan proses tagihan dan penerimaan atas pembayaran tunai penerbangan non regular tidak terdapat pemisahan tugas.

Atas uraian data-data diatas, disimpulkan bahwa pemisahan tugas sangat lemah sekali. Pemisahan tugas dan fungsi yang jelas akan meminimalkan risiko kecurangan. Dengan belum dilaksanakan pemisahan ini maka akan sangat berisiko terjadi kecurangan, sebab tidak dilakukan control, otorisasi atau verifikasi.

\section{Penilaian Kinerja Pegawai}

Penilaian kinerja adalah kegiatan untuk mengevaluasi perilaku prestasi kerja pegawai serta menetapkan kebijakan selanjutnya. Penilaian perilaku meliputi penilaian kesetiaan, kejujuran, kepemimpinan, kerja sama, loyalitas, dedikasi, dan partisipasi pegawai. Penilaian kinerja adalah evaluasi yang sistematis terhadap pekerjaan yang telah dilakukan oleh pegawai dan ditujukan untuk pengembangan. Tujuan penilaian kinerja pegawai adalah sebagai dasar dalam pengambilan keputusan yang digunakan untuk promosi, mutasi atau pemberian intensif.

Uraian yang dikemukakan diatas menunjukkan pengendalian aktivitas belum diterapkan secara utuh. Pengendalian aktivtas dalam kerangka COSO merupakan kebijakan dan prosedur yang membantu pimpinan bahwa apa yang disampaikan atau diarahkan telah dijalankan.

Agency ANATL telah mengembangkan aktivitas pengendalian yang meminimalkan risiko. Hal ini disebabkan aktivitas pelayanan jasa kebandaraan selalu berhubungan dengan teknologi. Observasi di lapangan, kegiatan-kegiatan yang dilakukan di lingkungan ANATL didasarkan pada SOP.

Pengendalian aktivitas yang paling lemah adalah pemisahan tugas dan fungsi, otorisasi, keamanan aset, dan verifikasi. Lemahnya pengendalian aktivitas ini akan memicu terjadi penyimpangan seperti kebocoran kas, raibnya perlengkapan dan persediaan, dan sebagainya. Konsep COSO menegaskan bahwa setiap pekerja/personil selalu berhubungan dengan orang lain, sehingga seorang dapat mengawasi teman yang ada disekelilingnya. 


\section{Informasi dan Komunikasi}

Informasi dan komunikasi dalam dunia penerbangan mempunyai peran dominan. Baik Informasi yang dihasilkan internal maupun dari pihak luar harus relevan dan berkualitas untuk mendukung komponen lain dalam rangka terlaksananya suatu sistem operasi. Informasi yang bersifat internal maupun eksternal harus benarbenar dikendalikan. Apabila pengendalian internal atas informasi dan komunikasi tidak dikendalikan maka sistem operasional pelayanan jasa kebandaraan akan terganggu.

Informasi baik diperoleh maupun dihasilkan, yang berhubungan dengan penerbangan secara refleks harus dikomunikasikan di kalangan internal maupun komponen-komponen lain seperti airline/operators, ground handling services dan sebagainya agar terjadi operasi yang sinergi.

Berdasarkan telaah dokumen dan observasi disimpulkan bahwa komunikasi dengan pihak eksternal untuk mengembangkan bandara menjadi lebih maju sama sekali belum dilakukan. Begitu pula komunikasi internal yang ditujukan bagi pengendalian internal belum diterapkan. Sebagai contoh, prosedur yang harus dilakukan dalam memungut airpot tax yang diabaikan pegawai, tidak segera dilakukan komunikasi internal untuk perbaikan. Tetapi secara umum komponen pengendalian informasi dan komunikasi yang berkaitan dengan operasional telah dilaksanakan secara memadai di agency ANATL.

\section{Monitoring}

Monitoring dalam konsep kerangka COSO terkait dengan: pengawasan yang berkesinambungan (on going monitoring), evaluasi yang terpisah atau kombinasi (separate evaluation); dan penyelesaian temuan hasil audit (Moeller, 2009).

\section{On going monitoring}

Aktifitas pemantauan (monitoring) berkaitan dengan penilaian efektifitas rancangan dan operasi struktur pengendalian intern secara periodik dan terus menerus oleh manajemen untuk melihat apakah telah dilaksanakan dengan semestinya dan telah diperbaiki sesuai keadaan.

Penelaahan terkait on going monitoring sangat lemah. Pengawasan dilakukan terus menerus tidak dapat dilaksanakan, oleh sebab Agency ANATL belum mengembangkan komponen terpisah (Internal Audit) untuk memastikan berfungsinya komponen lain "ada dan berfungsi".

ANATL sebagai services provider dunia penerbangan akan selalu dituntut untuk memberikan suatu kualitas pelayanan yang memadai. Tujuan ini akan tercapai bilamana jajaran manajemen berkomitmen tinggi untuk memajukan dan mengembangkan bandara dengan orientasi bisnis dengan penerapan pengendalian internal yang sesuai dan pembentukan komponen terpisah (Internal Audit).

\section{Separate Evaluation}

Evaluasi secara terpisah telah dilakukan, dengan adanya audit yang dilakukan pihak eksternal. Audit Kepatuhan dilakasanakan oleh ICAO Universal Safety Oversight Audit Programme (USOAP) dan Dewan Audit (Câmara de Contas, Tribunal de Recurco). Audit Keuangan dilakukan Ernest \& Young dan Deloitte 
yang dikontrak secara bergantian oleh Kementerian Keuangan Negara TimorLeste.

\section{Penyelesaian temuan hasil audit}

Penyelesaian temuan hasil audit masih belum dilaksanakan. Rekomendasirekomendasi yang ada, baik 54 temuan Tim Audit ICAO maupun Dewan Audit, Tribunal das Contas jika tidak segera dievaluasi maka permasalahan semakin membengkak. Untuk memperbaiki kinerja agency maka jajaran manajamen harus mengambil langkah-langkah perbaikan sesuai rekomendasi Tim Audit. Hal ini terlaksana apabila ada komitmen dari manajemen untuk menempuh langkah konkrit memperbaiki defisiensi-defisiensi yang ada.

ANATL belum melaksanakan rekomendasi-rekomendasi, menunjukkan agency tidak berkomitmen melakukan evaluasi secara terus menerus terhadap defisiensi-defisiensi yang ditemukan Tim Audit. Tindakan korektif yang tidak segera dilaksanakan juga menunjukkan komitmen manajemen atas pengendalian internal masih sangat lemah.

\section{Kasus-kasus di agency ANATL}

Consórcio ANA/NAV/ADA adalah perusahaan publik bandara Portugal yang diberi mandat untuk mempersiapkan masa transisi di bidang kebandar-udaraan. Dokumentasi rekaman arsip yang diperoleh penulis menunjukkan ANA Consórcio selama 15 bulan (1-3-2001 s/d 31-5-2002) telah mempersiapkan masa transisi. Persiapan dilakukan dengan rehabilitasi infrastruktur, instalasi peralatan komunikasi, rekrutmen untuk operasional dan menjalin kerja sama dengan pihak luar (Negara lain).

Tujuan daripada misi transisi adalah untuk berfungsinya bandara secara komersial setelah restorasi kemerdekaan Timor-Leste. Untuk mencapai tujuan ini ANA Consórcio melakukan perekrutan dan pelatihan personil lokal, yang bertanggung jawab mengoperasikan bandara Comoro-Dil.

Semenjak tahun 2011 timbul fenomena-fenomena yang menjadi sorotan media sebagaimana telah diuraikan pada latar belakang permasalahan. Suatu alasan logis sehubungan dengan fenomena-fenomena yang terjadi masalah kesejahteraan atau standar skala gaji yang belum disesuaikan dan UU yang belum diimplementasikan.

Sesuai UU No. 8/2005 bahwa Ministerio dos Transportes e Communicações dan Ministerio do Plano e das Finanças (pasal 4 dan pasal 24-25 bertugas menetapkan aturan-aturan tentang manajemen ekonomi dan keuangan (gestão económia $e$ financeira) sebagai wujud penjabaran UU tersebut. Kenyataan hingga saat ini belum dilakukan.

Lemahnya penegakan hukum dan peraturan yang ada akan memicu perilaku menyimpang dari sebagian pegawai yang pada akhirnya melemahkan pengendalian internal. Atau sebaliknya, lemahnya pengendalian internal disebabkan lemahnya kepatuhan pada aturan yang berlaku. 
Lemahnya penegakan aturan akan melemahkan pengendalain yang merupakan tanggung jawab jajaran manajemen. Dengan demikian membuktikan konsep pengendalian internal kerangka COSO yang menyatakan, sebaik apapun sistem dan aturan yang ditetapkan, jikalau tidak ada komitmen manajemen untuk menjalankannya maka akan sia-sia.

Beberapa penelitian sebelumnya menunjukkan hasil yang positif atau kinerja yang memadai sehubungan dengan penerapan pengendalian internal. Tetapi apabila tidak disertai komitmen dari pimpinan organisasi maka hasilnya akan berbanding terbalik.

Pemisahan tugas di ANATL merupakan unsur yang paling lemah. Petugas operasional yang bertugas (duty ship) dapat menerbitkan invoice, menerima uang, menyimpan dan baru disetorkan. Dapat disimpulkan bahwa, tidak dilakukan pemisahan fungsi, otorisasi, verifikasi dan pengawasan maka dapat terjadi penyimpangan aktiva/kas. Sesuai konsep COSO harus ada pemisahan tugas dan fungsi yang jelas, dilakukan otorisasi dan verifikasi sehingga kecurangan dapat dihindarkan.

Penelitian COSO yang menelaah hampir 350 kasus dugaan kecurangan pelaporan keuangan menunjukkan hasil bahwa kecurangan keuangan terjadi pada semua jenis ukuran perusahaan. Kecurangan mengenai pendapatan tercatat lebih $60 \%$ dari kasus. Aktivitas kecurangan pendapatan dikarenakan pencurian oleh pegawai sendiri, dengan prosentase yang lebih besar yakni $38 \%$.

Kevakuman ANATL pada suatu ketika akan berdampak pada pelayanan jasa kebandaraan dan menghambat proses pengembangan dan pembangunan baik penerbangan domestik maupun internasional. Bila telah difungsikan ANATL sebagai perusahaan umum Negara, maka dapat dikelola dengan pendekatan orientasi bisnis. Dalam hal ini sudah tentu Dewan Komisaris ANATL akan berusaha menjalin mitra usaha dengan pihak investor untuk menggarap dan mengelola bidang-bidang yang sama sekali belum disentuh untuk membangun bandara kearah yang lebih maju.

Berdasarkan hasil wawancara dan rekam dokumen disimpulkan bahwa kinerja ANATL yang disinyalir menurun, adanya penyimpangan atau fenomenafenomena yang terjadi, dan adanya perbedaan interpretasi merupakan perilaku pegawai yang disebabkan tidak ditegakkan hukum dan aturan yang ada. Perilakuperilaku yang tidak patuh pada hukum dan aturan yang ada, apabila tidak secara serius dilakukan pengendalian, jelas akan mempengaruhi aktivitas operasional dan kinerja ANATL tidak mencapai target/sasaran. Pengendalian internal atas pegawai merupakan aspek paling penting dalam memberikan pelayanan jasa (services provider).

\section{Perlunya penerapan Internal kerangka COSO di agency ANATL}

ANATL sebagai suatu lembaga BUMN yang eksis di Negara yang lahir pada abad 21 ini, tentu saja memiliki kelemahan-kelemahan atau kekurangan-kekurangan sebagaimana dinyatakan Director ANATL/Civil Aviation Timor-Leste. Hasil penelitian menunjukkan pengendalian internal agency ANATL sangat lemah, 
maka ANATL perlu mengadopsi framework COSO, sama halnya dengan standarstandar lain yang telah diadopsi, sebagai suatu langkah dan upaya agar penyelenggaraan tugas dan fungsi berjalan efisien dan efektif.

Olach dan Weeramantri (2009) yang telah melakukan penelitian lebih dari 20 tahun, menjelaskan bahwa COSO telah membantu menciptakan pola pikir yang berorientasi kontrol bagi manajer dan auditor internal sehingga risiko dan masalah pengendalian dapat dilihat secara konsisten, baik secara internal maupun eksternal.

Mengadopsi framework COSO juga sebagai upaya mengisi kekosongan aturan pengendalian internal yang belum ditetapkan oleh ANATL. Dari penelusuran dokumen arsip, terdapat dokumen Policy and Procedures Manual for Revenue Recognition dimana ditentukan juga pengendalian internal. Tetapi kebijakan tersebut hanya untuk pengendalian atas pendapatan agency ANATL. Kerangka COSO yang diterbitkan pada tahun 1992 dan telah mengalami beberapa kali penyempuraan, juga telah diterima secara luas di dunia dan berdasarkan sebuah polling oleh majalah CFO yang dikeluarkan pada tahun 2006, 82\% responden mengaku menggunakan kerangka COSO untuk pengendalian internal, maka tidak keliru bagi ANATL untuk mengadopsinya.

Hasil penelitian Lakis dan Giri (2012) menyajikan generalisasi inklusif dan definisi pengendalian internal bahwa: sistem pengendalian internal merupakan bagian sistem manajemen perusahaan untuk memastikan pelaksanaan tujuan perusahaan, mencapai kinerja komersial-ekonomi yang efektif, ketaatan prinsip akuntansi dan kontrol yang efektif atas risiko kerja, aktif meminimalkan jumlah kesalahan yang disengaja dan tidak disengaja, dan untuk menghindari penipuan dalam proses kinerja perusahaan yang dibuat oleh otoritas atau karyawannya.

Penelitian Santoso (2013) juga menyimpulkan penerapan aktivitas yang disesuaikan kerangka COSO 2012 dapat meningkatkan efektivitas dan efisiensi dari pengendalian internal perusahaan, juga dapat memitigasi risiko, dan mengurangi celah kelemahan atas kebijakan dan prosedur yang ada untuk meminimalkan kerugian yang terjadi.

ANATL yang merupakan perusahaan publik mempunyai kewajiban untuk menetapkan suatu sistem pengendalian internal yang efektif untuk mengamankan investasi dan aset perusahaan. Disamping itu ANATL harus dapat mengelola risiko usaha dalam setiap pengambilan keputusan/tindakan, mengingat dalam era globalisasi ini terjadi perubahan lingkungan bisnis yang sangat cepat.

Sistem pengendalian internal berbasis coso merupakan jawaban dari permasalahan yang dipicu adanya kasus-kasus besar yang telah melakukan pembohongan publik dengan melakukan manipulasi dalam pelaporan dan mengakibatkan kerugian bagi investor, seperti kasus Enron dan lainnya. Sedangkan di sektor publik atau pemerintahan banyak ditunjukkan dengan adanya kasus korupsi dan kolusi yang merugikan keuangan negara. 
Konsep sistem pengendalian internal COSO memberi tekanan pada suatu proses (process oriented), bukan merupakan tujuan, terbatas pada memberikan keyakinan yang memadai, bukan jaminan terhadap pencapaian tujuan organisasi, dan hanya efektif kalau semua pihak terlibat didalamnya (all management level envolved). Kerangka COSO mengakui bahwa:

1. Lima komponen kerangka COSO diperlukan bagi pengendalian internal yang efektif (five components of internal control are necessary for effective internal control).

2. Pengendalian internal dirancang untuk membantu organisasi dalam mencapai tujuan pada keseluruhan operasi, pelaporan keuangan, dan kepatuhan (internal control is designed to assist the organization in achieving its objectives across operations, financial reporting, and compliance).

3. Konsep dasar pengendalian internal berlaku untuk semua organisasi: besar atau kecil, laba dan nirlaba, dan badan-badan pemerintah (the fundamental concepts of internal control apply to all organizations: large or small, for profit and not for profit, and governmental entities).

4. Manajemen bertanggung jawab atas pengendalian internal yang efektif, dengan pengawasan aktif oleh dewan dan orang-orang di posisi pemerintahan (management is responsible for effective internal control, with active oversight by boards and those in governance positions).

5. Kerangka COSO harus menjadi gaung fundamental yang memungkinkan proses pengendalian internal spesifik yang berkembang seiring dengan perubahan dalam bisnis, teknologi, dan resiko (the framework must be fundamentally sound to allow specific internal control processes to evolve with changes in business, technology, and risk).

Kerangka kerja COSO tidak kaku, pendekatannya bersifat memberi pedoman bagi pengendalian internal. Ini berarti suatu perusahaan akan berbeda dengan perusahaan lain dalam mengontrol bisnisnya. Karena keadaan yang berubah dalam suatu organisasi, maka pengendalian internal harus di rancang dalam menghadapi perubahan dan tetap efektif dalam lingkungan yang dinamis. Kenyataannya salah satu tujuan utama dari komponen pengendalian internal yaitu "monitoring" adalah menilai kualitas dari kinerja sistem dari waktu ke waktu, mengakui bahwa keadaan akan berubah.

Hasil penelitian sebelumnya menunjukkan konsep pengendalian internal framework COSO yang dapat diterapkan pada organisasi apapun, yang mempunyai tujuan untuk efektivitas dan efisiensi kegiatan organisasi.

cOSO mengakui adanya keterbatasan dalam internal control. Seberapapun bagusnya dirancang dan dilaksanakan, pengendalian internal hanya dapat memberikan jaminan yang wajar bahwa sasarannya akan tercapai.

\section{KESIMPULAN}

Berdasarkan hasil penelitian yang dilakukan di Administração e Navegação Aérea de Timor Leste (ANATL) maka disimpulkan bahwa : 
1. Komponen lingkungan pengendalian agency ANATL lemah pada struktur organisasi, delegasi wewenang, komitmen terhadap kompetensi, serta kebijakan dan praktik sumber daya manusia.

2. Komponen penilaian risiko sudah sesuai dengan konsep COSO oleh karena ANATL telah menetapkan aturan dan prosedur untuk mengindentifikasi risiko, menganalisisnya dan mengelola risiko yang timbul, namun terdapat prosedur-prosedur yang diabaikan sehinggaakan menimbulkan risiko fraud.

3. Komponen pengendalian aktivitas ANATL paling lemah adalah pemisahan tugas dan fungsi, otorisasi, keamanan aset, dan verifikasi. Lemahnya pengendalian aktivitas akan memicu terjadi penyimpangan seperti kebocoran kas, raibnya perlengkapan dan persediaan, dan sebagainya.

4. Komponen informasi dan komunikasi telah dilaksanakan secara memadai di agency ANATL, hanya saja komunikasi dengan pihak eksternal untuk mengembangkan bandara menjadi lebih maju belum dilakukan. Begitu pula komunikasi internal yang ditujukan bagi pengendalian internal belum diterapkan.

5. Komponen Monotoring sangat lemah karena:

a. On going monitoring belum dilaksanakan oleh sebab belum terbentuk komponen terpisah (Internal Audit);

b. Evaluasi secara terpisah telah dilakukan, dengan adanya audit eksternal. Penyelesaian temuan hasil audit, rekomendasi-rekomendasi Tim Audit belum ditindak-lanjuti oleh ANATL.

6. Implementasi pengendalian internal di agency ANATL sesuai keranga COSO sangat lemah hampir pada semua komponen-komponen maka Proposisi 1 terjawab yaitu: jika impelemtasi pengendalian internal secara utuh maka kinerja agency ANATL akan sangat baik, ternyata penerapan pengendalian internal secara tidak utuh menyebabkan kinerja ANATL buruk.

Fenomena-fenomena yang terjadi merupakan perilaku pegawai oleh karena tidak ditegakkan hukum dan aturan yang ada. Kelemahan ini berdampak pada perilaku fraud yang melemahkan penerapan pengendalian internal. Dengan demikian disimpulkan kualitas pengendalian internal buruk atau tidak memadai, dan Proposisi 2 terjawab: Kualitas pengendalian internal semakin baik, semakin kecil resiko yang timbul dan kecurangan dapat dicegah, ternyata kualitas pengendalian internal buruk akan berisiko dan menyebabkan terjadinya kecurangan (fraud). 


\section{DAFTAR REFERENSI}

Arens, A. A., Elder, R. J., \& Beasley, M. S. 2012. Auditing and assurance services: an integrated approach.

Arruda, J. 2005. Comoro - Um Aeroporto em Timor-Leste: Maisimagem - Comunicação Global, Lda.

Auditing Standard No. 5 An Audit of Pengendalian internalOver Financial Reporting That Is Integrated with An Audit of Financial Statements, from http://pcaobus.org/Standards/Auditing/Pages/Auditing_Standard_5.aspx

Bennett, G. E. 1930. Fraud: its control through accounts: Century Co.

Brown, N. C., Pott, C., \& Wömpener, A. 2008. The effect of internal control regulation on earnings quality: Evidence from Germany. $A A A$ Financial Accounting and Reporting Section (FARS) Paper.

Creswell, J. W. 2013. Research design: Qualitative, quantitative, and mixed methods approaches: Sage Publications, Incorporated.

Cunningham, G. M., \& Harris, J. E. 2006. Enron and Arthur Andersen: The Case of the Crooked E and the Fallen A. Global Perspectives on Accounting Education, 3(1), 3.

D'Aquila, J. 2013. COSO's Internal Control Integrated Framework Updating the Original Concepts for Today's Environment. The CPA Journal, 83(10), 22-29.

Dewi, S. P. 2012. Pengaruh Pengendalian Internal dan Gaya Kepemimpinan Terhadap Kinerja Karyawan SPBU Yogyakarta (Studi Kasus pada SPBU Anak Cabang Perusahaan RB. Group). Nominal: Barometer Riset Akuntansi dan Manajemen, 1(1).

Firnanda, D. K. R. 2013. System of Internal Control of Revenue Cycle (Study Case At CV. Sinar Terang Distributor). Jurnal IImiah Mahasiswa FEB, 1(1).

Hermanson, D. R., Smith, J. L., \& Stephens, N. M. 2012. How Effective are Organizations' Internal Controls? Insights into Specific Internal Control Elements. Current Issues in Auditing, 6(1), A31-A50. doi: 10.2308/ciia-50146

Konrath, L. F. 1999. Auditing Concepts and Applications: A Risk Analysis Approach: SouthWestern College Publishing.

Laine, S., Marscholl, P., Ngoc, A. N., \& Osche, T. 2013. Internal control and risk management-structures and processes. Corporate Governance.

Lakis, V., \& Giri nas, L. 2012. THE CONCEPT OF INTERNAL CONTROL SYSTEM: THEORETICAL ASPECT. Ekonomika/Economics, 91(2).

Long, M. L. 2009. Internal Controls for Small Businesses to Reduce the Risk of Fraud. (Intuit, Inc. All rights reserved. 5601 Headquarters Drive).

Moeller, R. R. 2004. Sarbanes-Oxley and the new internal auditing rules: John Wiley \& Sons.

Moeller, R. R. 2009. Brink's modern internal auditing: a common body of knowledge: Wiley. com.

Moleong, L. J. 2013. Metodologi Penelitian Kualitatif (Edisi Revisi ed.). Bandung: PT. Remaja Rosdakarya. 
Neuman, W. L. 2013. Metode Penelitian Sosial: Pendekatan Kualitatif dan Kuantatif (E. T. Sofia, Trans. 7th ed.). 75 Arlington Street, Suite 300, Boston, MA 02116: Pearson Education, Inc.

Olach, T., \& Weeramantri, S. 2009. How COSO has improved internal controls in the United States. Internal Auditing, 24(6), 3.

Reding, K. F., Sobel, P. J., Anderson, U. L., Head, M. J., Ramamoorti, S., Salamasick, M., \& Riddle, C. 2009. Internal Auditing: Assurance \& Consulting Services, 2nd Edition: The Institute of Internal Auditors Research Foundation.

Santoso, P. A. 2013. Evaluasi Penerapan Internal Control Berdasarkan Kerangka COSO 2012 pada Divisi Kartu Kredit di Bank "X". CALYPTRA: Jurnal IImiah Mahasiswa Universitas Surabaya, 1(1).

Sawyer, L. B. 2005. Sawyers Internal Auditing: The Practice of Modern Internal Auditing$5 / E$.

Sawyer, L. B., Dittenhofer, M. A., \& Scheiner, J. H. 2005. Sawyer's internal auditing (5/E ed.). Jakarta, Salemba Empat: Institute of Internal Auditors.

Schneider, K. N., \& Becker, L. L. 2011. Using the COSO model of internal control as a framework for ethics initiatives in business schools.

Setiyawati, H. 2013. The effect of Internal Accountants' Competence, Managers' Commitment to Organizations and the Implementation of the Internal Control System on the Quality of Financial Reporting.

Singleton, T. 2002. Stop fraud cold with powerful internal controls. The Journal of Corporate Accounting \& Finance, 13(4), 29-39.

Singleton, T. 2007. IT Audit Basics: The COSO Model: How IT Auditors Can Use It to Evaluate the Effectiveness of Internal Controls. Information Systems Control Journal, 6, 13.

Sugiyono. 2012. Metode Penelitian Bisnis (Cetakan ke-16 ed.). Bandung: Alfabeta.

Sutariono, S. M. 2013. Analisis Pencegahan Dan Pendeteksian Risiko-Risiko Operasional Perusahaan Berdasarkan COSO Internal Control Integrated Framework (Studi Kasus PT. XYZ). Jurnal Ilmiah Universitas Bakrie, 1(02).

Tseng, C.-Y. 2007. Internal Control, Enterprise Risk Management, and Firm Performance.

Yin, R. K. 2012. Studi Kasus Desain dan Metode (M. D. Mudzakir, Trans. Cetakan ke-11, Maret 2012 ed.): Jakarta: RajaGrafindo Persada.

Pemerintah RDTL Decreto-Lei n. ${ }^{\circ}$ 14/2003, de 24 de Setembro Criação a Empresa Pública

Pemerintah RDTL Decreto-Lei n. ${ }^{\circ}$ 8/2005, de 16 de Novembro Criação a Empresa Pública Administração de Aeroportos e Navegação Aérea de Timor - Leste, E.P (ANATL ,E.P.)

Funcionários do Aeroporto Internacional Nicolau Lobato ameaçam entrar em greve, 2013 download dari http://www.timorhauniandoben.com/2013/02/fatin-laihamakina-x-ray-aeroporto.html. 
Konstrusaun Aeroportu Internasional PNL, Planu tinan 5 halo dezeñu seidauk hotu, 2013, download dari http://www.jornalbisnistimor.com/notisia/ekonomia/ 1002konstrusaun-aeroportu-pnl-planu-tinan-5-halo-dezenu-seidauk-hotu.

SAPO TL com Suara Timor Lorosa'e, 2011, download dari http://paginaglobal. blogspot.com/2011/10/timor-leste-funcionarios-do-aeroporto.html.

Servico Aviasaun Civil TL Kastigu Aviaun Air North Iha Dili, 2013, download dari http://www.temposemanal.com/nasional/servico-aviasaun-civil-tl-kastiguaviaun-air-north-iha-dili 